\title{
KETERAMPILAN BERBAHASA SISWA PAKET C SANGGAR KEGIATAN BELAJAR (SKB) BALIKPAPAN TIMUR
}

\author{
Savira Saraswati ${ }^{1}$, Casmudi $^{2}$, Retnowaty ${ }^{3}$ \\ Universitas Balikpapan ${ }^{1}$, Universitas Balikpapan ${ }^{2}$, Universitas Balikpapan ${ }^{3}$ \\ pos-el: saraswatisavira@gmail.com¹, casmudibpn62@gmail.com², retnowaty@uniba-bpn.ac.id ${ }^{3}$
}

\begin{abstract}
ABSTRAK
Sebagai dasar dari mata pelajaran Bahasa Indonesia, keterampilan berbahasa sangat penting untuk dikuasai. Jika siswa kurang menguasai keterampilan berbahasa, maka akan berpengaruh kepada pengetahuan siswa yang lain, karena keterampilan berbahasa juga dasar dari berkomunikasi. Penelitian ini bertujuan untuk mengetahui keterampilan berbahasa yang terdiri dari keterampilan menyimak, berbicara, membaca, dan menulis siswa paket C SKB Balikpapan Timur serta hambatan siswa untuk menguasai keterampilan berbahasa dan solusi dari hambatan tersebut. Jenis penelitian ini adalah deskriptif kualitatif. Teknik pengumpulan data penelitian ini melalui observasi, wawancara, dan dokumentasi. Instrumen yang digunakan berupa panduan observasi, wawancara, telepon genggam, alat tulis, catatan lapangan, dan kartu data. Penelitian ini menggunakan teknik analisis data berupa reduksi data, penyajian data, dan penarikan kesimpulan serta verifikasi. Hasil penelitian ini menunjukkan bahawa secara umum keterampilan berbahasa siswa paket C SKB Balikpapan Timur dalam kategori cukup. Untuk masing-masing aspek didapatkan hasil bahwa keterampilan menyimak siswa baik, keterampilan membaca baik, keterampilan berbicara kurang, dan keterampilan menulis kurang. Hambatan siswa dalam menguasai keterampilan berbahsa adalah tidak adanya buku pedoman pembelajara secara fisik, guru tidak menjelaskan materi secara fisik, guru tidak mengembangkan keterampilan berbahasa yang telah dimiliki siswa, siswa tidak tertarik dengan guru, dan siswa tidak tertarik dengan materi yang diajarkan.
\end{abstract}

Kata kunci : Keterampilan Berbahasa, Paket C, Sanggar Kegiatan Belajar.

\begin{abstract}
As the basis of Indonesian subjects, language skills are very important to master. If students do not master language skills, it will affect the knowledge of other students, because language skills are also the basis of communication. This study aims to determine language skills consisting of listening, speaking, reading, and writing skills of students in package C SKB East Balikpapan as well as students' obstacles to mastering language skills and solutions to these obstacles. This type of research is descriptive qualitative. The data collection techniques of this study were through observation, interviews, and documentation. The instruments used were observation guides, interviews, cell phones, stationery, field notes, and data cards. This study uses data analysis techniques such as data reduction, data presentation, and drawing conclusions and verification. The results of this study indicate that in general the language skills of students in Package C of East Balikpapan SKB are in the moderate category. For each aspect the results were obtained that students' listening skills were good, reading skills were good, speaking skills were lacking, and writing skills were lacking. Barriers to students in mastering language skills are the absence of a physical learning manual, the teacher does not explain the material physically, the teacher does not develop the language skills students have, students are not interested in the teacher, and students are not interested in the material being taught.
\end{abstract}

Keywords: Language Skills, C Package, Studio Learning Activities. 


\section{PENDAHULUAN}

Dalam mengatasi masalah pendidikan bagi anak-anak yang tidak bersekolah dan masyarakat yang belum memiliki ijazah, program pendidikan kesetaraan salah satunya dapat diberikan melalui Sanggar Kegiatan Belajar (SKB). Program belajar di SKB terbagi menjadi tiga tingkatan yaitu paket A setara Sekolah dasar, paket B setara Sekolah Menengah Pertama dan paket C setara Sekolah Menengah Atas. Di dalam SKB, masyarakat menjadi lebih mudah untuk mendapatkan pendidikan sebagaimana haknya, karena SKB menggunakan sistem pembelajaran yang dirancang secara khusus dan berbeda dari sekolah formal agar memiliki daya tarik tersendiri bagi siswa untuk lebih bersemangat memperoleh pengetahuan.

Salah satu mata pelajaran umum yang diajarkan di SKB Balikpapan Timur adalah bahasa Indonesia. Dalam mempelajari bahasa Indonesia terdapat keterampilan berbahasa yang terdiri dari menyimak, berbicara, membaca dan menulis. Keterampilan berbahasa merupakan dasar yang harus dikuasai siswa untuk dapat memperoleh pengetahuan baik akademik maupun non akademik. Dengan diajarkan melalui metode dan strategi pengajaran yang berbeda serta dengan melihat latar belakang siswa, maka pengetahuan keterampilan berbahasa siswa paket $\mathrm{C}$ SKB Balikpapan Timur berbeda dari siswa di sekolah formal.

Penelitian ini merujuk kepada penelitian yang telah dilakukan oleh Ida Kintamani tahun 2012 dengan judul Kinerja Pendidikan Kesetaraan Sebagai Salah Satu Jenis Pendidikan Nonformal. Tujuan penelitian tersebut untuk menganalisis sasaran pendidikan kesetaraan, profil, dan kinerja pendidikan kesetaraan. Metode yang digunakan adalah studi dokumentasi dengan menggunakan data pada tingkat nasional untuk menghitung lima indikator pemerataan dan tujuh indikator mutu pendidikan.

Keterampilan berbahasa menurut Tarigan (2015, hal. 2) adalah keterampilan yang terdiri dari empat aspek yang mulai dipelajari sejak masa kecil, yaitu belajar menyimak bahasa, kemudian berbicara dan setelah itu membaca serta menulis. Untuk aspek menyimak dan berbicara dipelajari sebelum memasuki sekolah dan aspek membaca dan menulis diperoleh di bangku sekolah. Keempat aspek tersebut adalah satu kesatuan yang disebut catur tunggal.

Menurut Hermawan (2012, hal. 30) menyimak merupakan keterampilan untuk memahami pemikiran, ide serta emosi yang ditunjukan orang lain secara lebih akurat. Faktor yang memengaruhi menyimak menurut Hermawan (2012, hal. 50) terbagi menjadi dua, yaitu faktor internal dan faktor eksternal.

Berbicara adalah keterampilan seseorang dalam mengucapkan bunyi artikulasi atau kata yang menggambarkan dan menyampaikan ide, pendapat serta perasaannya Tarigan (Satata \& dkk, 2012, hal. 73). Tujuan keterampilan berbicara menurut Nawawi \& dkk (2017, hal. 23) adalah memenuhi dan menata ide dengan pemikiran yang logis dan sistematis, mengubah ide ke dalam bentuk ujaran yang sesuai dengan kaidah Bahasa Indonesia, mampu berbicara dengan jelas, dan mampu menggunakan ragam bahasa.

Membaca adalah kegiatan atau proses kognitif sebagai upaya untuk mendapatkan segala informasi yang terdapat di dalam sebuah tulisan (Dalman, 2014, hal. 5). Menulis merupakan keterampilan yang paling sedikit digunakan diantara empat keterampilan yang dimiliki seseorang karena banyak yang belum mengetahui mengenai pengajaran keterampilan menulis (Aziez, 2015, hal. 171). Keterampilan menulis memiliki tujuan yang sama seperti berbicara, yaitu untuk memberikan sebuah informasi atau hanya sekedar ini 
menceritakan sesuatu yang terjadi. Tujuan tersebut dijelaskan oleh Dalman (2014, hal. 3) melalui definisinya, yaitu menulis merupakan suatu kegiatan komunikasi yang bertujuan untuk menyampaikan informasi kepada orang lain dengan menggunakan bahasa tulis sebagai perantaranya.

Sebagai satuan pendidikan nonformal, SKB memberikan pendidikan kesetaraan melalui program kejar paket A, B dan C. Abdulhak \& Suprayogi (2012, hal. 48) menjelaskan bahwa penyelenggaraan pendidikan kesetaraan dalam rangka mengurangi tuna aksara dan angka, tuna pengetahuan dasar dan tuna bahasa. Penyelenggaraan program kejar paket $\mathrm{A}, \mathrm{B}$ dan $\mathrm{C}$ pun dihubungkan dengan pembinaan dan pengembangan sesuai keterampilan fungsional peserta didik yang berkaitan dengan mata pencaharian, jadi program pengajarannya diintegrasikan dengan pendidikan mata pencaharian dalam rangka mengembangkan kehidupannya.

Walaupun berpedoman pada prinsip kurikulum kafetaria, tidak semua lembaga pendidikan nonformal dapat menyusun kurikulumnya sendiri. Dalam kurikulum yang telah di sempurnakan oleh Badan Satuan Nasional Pendidikan (BSNP) yaitu Kurikulum Tingkat Satuan Pendidikan (KTSP) juga mengatur mengenai pembelajaran serta standar kompetensi lulusan satuan pendidikan.

Dalam implementasinya, belajar adalah kegiatan individu dalam memperoleh pengetahuan, perilaku, dan keterampilan dengan cara mengelola bahan ajar (Komara, 2014 hal. 2). Tanpa kesiapan mental dalam belajar, maka peserta didik tidak akan bertahan terhadap berbagai kesulitan yang dihadapi selama belajar. Setiap peserta didik harus memiliki minat yang besar terhadap setiap mata pelajaran yang ditempuh. Jika siswa memiliki rasa benci terhadap mata pelajaran tertentu, maka sikap tersebut akan menjadi salah satu hambatan baginya dalam belajar.
Hambatan belajar juga bisa berasal dari dalam maupun luar diri seseorang. Menurut (Komara, 2014 hal. 19) hambatan-hambatan tersebut antara lain kesehatan fisik dan psikis yang kurang baik, kemampuan berlajar peserta didik yang rendah, sikap dan kebiasaan yang buruk seperti malas, pandangan negatif seperti rasa pesimis, rendah diri, cemas dan takut.

Sedangkan hambatan dari luar antara lain lingkungan yang kurang nyaman, sarana prasarana yang kurang memadai, keadaan kelas yang penuh dengan barang yang tidak diperlukan, pengaruh teman yang kurang baik, tidak adanya motivasi dari orang-orang terdekat.

\section{METODE PENELITIAN}

Penelitian ini menggunakan jenis penelitian deskriptif kualitatif. Data dalam penelitian ini berupa hasil tuturan yang disampaikan dari narasumber. Sedangkan sumber data dalam penelitian ini adalah beberapa tokoh narasumber yaitu Kepala SKB Balikpapan Timur, Kepala Pembimbing Paket C, Guru Bahasa Indonesia, dan 5 Siswa Paket C. Data dalam penelitian ini diperoleh melalui observasi, wawancara, dan dokumentasi. Data-data yang telah didapat, dianalisis melalui reduksi data, penyajian data, dan penarikan kesimpulan atau verifikasi. Setelah itu, pengecekan keabsahan data dalam penelitian ini menggunakan triangulasi sumber yaitu peneliti membandingkan hasil data yang didapat dari wawancara, observasi dan dokumentasi, serta perpanjangan keikutsertaan yaitu peneliti terjun langsung ke lokasi penelitian untuk mendapatkan data.

\section{HASIL DAN PEMBAHASAN}

Berdasarkan hasil observasi peneliti menemukan kondisi ruang kelas yang kurang memadai, sehingga hal tersebut menjadi salah satu faktor yang mempengaruhi kemampuan menyimak siswa. Hal tersebut juga dibenarkan oleh 
siswa saat wawancara. Selain itu, guru hanya menggunakan metode ceramah saat mengajar dan tidak menggunakan media pembelajaran sehingga siswa merasa bosan dengan pembelajaran bahasa Indonesia. SKB Balikpapan Timur juga tidak menyediakan buku pembelajaran secara fisik sehingga siswa kesulitan dalam mempelajari bahasa Indonesia. Sehingga didapatkan hasil keterampilan berbahasa siswa paket C SKB Balikpapan Timur masih dalam kategori cukup.

Keadaan keterampilan berbahasa siswa yang masih dalam kategori cukup, dikarenakan siswa hanya mampu menguasai dengan baik keterampilan menyimak dan keterampilan membaca, sedangkan untuk keterampilan berbicara dan menulis siswa masih kurang. Hal tersebut disebabkan oleh guru yang kurang melatih dan mengembangkan keterampilan berbahasa yang telah dimiliki siswa. Guru hanya melatih keterampilan menyimak dan membaca, sedangkan untuk keterampilan berbicara dan menulis guru jarang memberikan kegiatan pembelajaran yang melatih keterampilan tersebut.

Selain itu, tidak diterapkannya salah satu poin dalam Standar Kompetensi Lulusan SMA/MA/Paket $\mathrm{C}$ yang menyatakan bahwa setiap siswa harus menunjukkan keterampilan berbahasa yang terdiri dari menyimak, berbicara, membaca, dan menulis dengan baik, menjadi faktor penting penyebab mengapa keterampilan berbahasa siswa paket C SKB Balikpapan Timur masih dalam kategori cukup. Dengan tidak diterapkannya poin SKL tersebut dalam SKB Balikpapan Timur membuat guru menjadi kurang memiliki tanggung jawab untuk benar-benar melatih dan mengembangkan keterampilan berbahasa siswa.

Hambatan siswa dalam menguasai keterampilan berbahsa adalah tidak adanya buku pedoman pembelajara secara fisik, guru tidak menjelaskan materi secara fisik, guru tidak mengembangkan keterampilan berbahasa yang telah dimiliki siswa, siswa tidak tertarik dengan guru, dan siswa tidak tertarik dengan materi yang diajarkan.

Oleh karena itu, solusi untuk mengatasi hambatan yang ada maka SKB Balikpapan Timur perlu memberikan buku pembelajaran secara fisik, guru menjelaskan materi secara lebih rinci, guru mengembangkan keterampilan berbahasa yang telah dimiliki siswa, guru harus menarik perhatian siswa dengan menggunakan metode mengajar yang berbeda, serta guru harus memberikan materi dengan cara yang menarik agar siswa mau untuk mempelajari materi yang diberikan.

\section{KESIMPULAN}

Berdasarkan hasil penelitian dan pembahasan serta observasi dan wawancara yang telah peneliti lakukan dengan beberapa narasumber, maka dapat disimpulkan bahwa keterampilan berbahasa siswa paket C SKB Balikpapan Timur termasuk dalam kategori cukup. Meskipun terdapat kekurangan dari aspek-aspek keterampilan berbahasa yang dimiliki siswa, hal itu dapat diatasi dan dikembangkan dengan lebih baik lagi oleh guru maupun siswa itu sendiri. Secara rinci, siswa paket $\mathrm{C}$ SKB Balikpapan Timur telah memiliki keterampilan menyimak dan membaca yang baik. Sedangkan untuk keterampilan berbicara dan menulis masih dalam kategori kurang. Oleh karena itu berdasarkan hasil penelitian, keterampilan yang perlu dikembangkan dengan lebih serius adalah keterampilan berbicara dan keterampilan menulis siswa. Setidaknya agar kedua keterampilan tersebut dapat sama baiknya dengan dua keterampilan lain yang dimiliki siswa.

Perihal lain mengenai faktor yang menghambat siswa dalam menguasai keterampilan berbahasa adalah belum adanya buku pedoman yang dimiliki siswa, guru belum menjelaskan materi secara rinci, guru belum mengembangkan 
keterampilan berbahasa yang telah dimiliki siswa, siswa tidak tertarik dengan guru, dan siswa tidak tertarik dengan materi yang diajarkan. Selain itu kurangnya perhatian dari pemerintah mengenai sarana dan prasarana SKB Balikpapan Timur juga menjadi penghambat proses pembelajaran.

\section{DAFTAR PUSTAKA}

Abdulhak, I., \& Suprayogi, U. (2012). Penelitian Tindakan Dalam Pendidikan Nonformal. jakarta: PT Raja Grafindo Persada.

Aziez, F. (2015). Pengajaran Bahasa Komunikatif. Yogyakarta: Pustaka Pelajar.

Dalman. (2014). Keterampilan Membaca. Jakarta: PT Rajagrafindo Persada.

Dalman. (2014). Keterampilan Menulis. Jakarta: Rajagrafindo Persada.

Hermawan, H. (2012). Menyimak : Keterampilan Berkomunikasi yang Terabaikan. Yogyakarta: Graha Ilmu.

Kintamani, I. (2012). Kinerja Pendidikan Kesetaraan Sebagai Salah Satu Jenis Pendidikan Nonformal. Jurnal Pendidikan dan Kebudayaan , Vol.18 No.1, 65-84.

Komara, E. (2014). Belajar dan Pembelajaran Interaktif. Bandung: PT Refika Aditama.

Mulyasa. (2009). Kurikulum Tingkat Satuan Pendidikan Sebuah Panduan Praktis. Bandung: PT Remaja Rosdakarya.

Nawawi, \& dkk. (2017). Keterampilan Berbicara Sebagai suatu keterampilan berbahasa. Jakarta: Uhamka Press.

Satata, S., \& dkk. (2012). Bahasa Indonesia. Jakarta: Mitra Wacana Media.

Tarigan, H. G. (2015). Membaca Sebagai Suatu Keterampilan Berbahasa. Bandung: CV Angkasa. 